
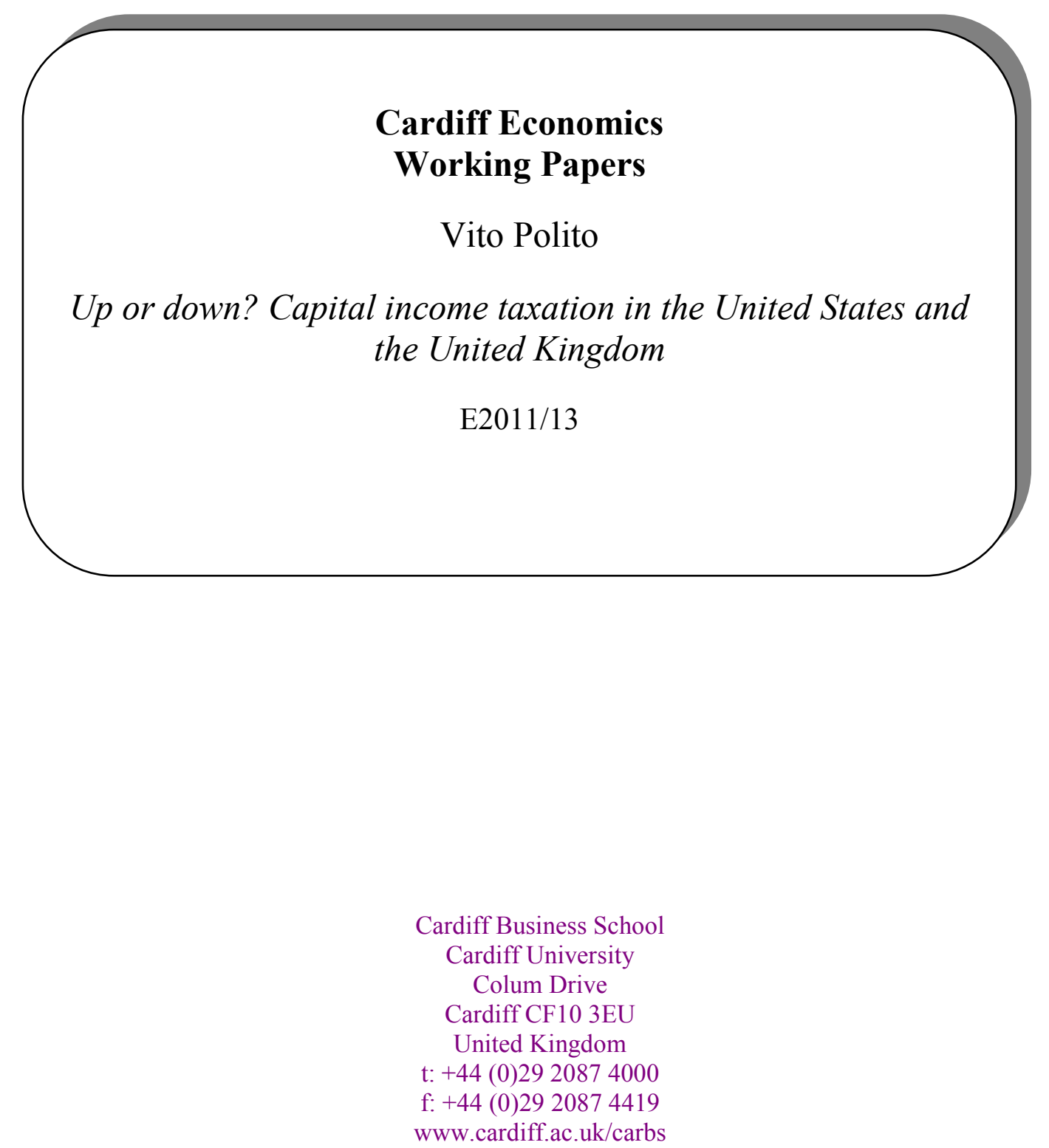

ISSN 1749-6101

June 2011

This working paper is produced for discussion purpose only. These working papers are expected to be published in due course, in revised form, and should not be quoted or cited without the author's written permission.

Cardiff Economics Working Papers are available online from: http://www.cardiff.ac.uk/carbs/econ/workingpapers Enquiries: EconWP@cardiff.ac.uk 


\title{
Up or down? Capital income taxation in the United States and the United Kingdom
}

\author{
Vito Polito \\ Cardiff Business School \\ University of Cardiff
}

January 2011

\begin{abstract}
Empirical evidence suggests that the Effective Marginal Tax Rate (EMTR) on income from capital has increased considerably in both the United States and the United Kingdom over the period 1982-2005. This evidence contradicts the corporate tax literature which predicts that the EMTR should instead fall over time as a result of increasing international capital mobility and higher tax competition between governments. This paper argues that this inconsistency is entirely due to the fact that EMTRs on income from capital are currently computed from versions of the neoclassical investment model which do not take into account financial constraints on dividend policy faced by firms investing in both the United States and the United Kingdom. The paper incorporates financial constraints on dividend policy into the analytical framework for the computation of the EMTR and employs the new model to re-calculate time series of the EMTRs in both countries. The new empirical results show that, in contrast to the existing evidence, the EMTR on investment financed by either retained earnings or new equity has indeed declined over time in both countries, while the EMTR on debt-financed investment has remained relatively stable.
\end{abstract}

Keywords: Capital income taxation; dividend policy; effective marginal tax rates; financial constraints.

JEL classification: H3.

Acknowledgments: I would like to thank Alexander Klemm for sharing his earlier data set; Ernesto Longobardi, Patrick Minford, Paolo Panteghini, Assaf Razin and Partho Shome for useful comments; participants at the CESifo Conference on Corporate Taxes and Corporate Governance (Munich, November 2010); and seminar participants Cardiff Business School, Brescia Economics Department and HM Revenue and Customs. 


\section{Introduction}

Since they were first introduced by King and Fullerton (1984), Effective Marginal Tax Rates (EMTRs) on income from capital have been widely used by international organisations and policy-makers, in both the United States and Europe, for cross-country comparisons of the corporate tax burden and to support reforms in public policy. ${ }^{1}$ Time series of EMTRs are also extensively used in the empirical literature to assess the determinants of foreign direct investment, the effects of corporate income taxation on the international allocation of capital, and the economic impact of tax policy reforms. ${ }^{2}$

The EMTR is computed from the neoclassical investment model as the ratio between taxes levied on a hypothetical investment project earning the marginal rate of return and either the pre-tax or post-tax return earned by the same project. The main advantage of the EMTR is that it provides a single measure of the effective tax burden on income from capital which simultaneously takes into account the impact of statutory tax rates and rules on the tax base assessment. As prescribed by the traditional neoclassical investment literature pioneered by Jorgenson (1963) and Jorgenson and Hall (1967), the impact of the rules for the tax base assessment on the EMTR is captured by the effect that tax allowances for capital spending have on the return of income from capital. In particular, according to the standard theory, the effective tax burden falls when the tax code grants higher tax allowances for capital spending. The incentive works because firms can then defer part of their tax liability to the future, in turn increasing the present value of dividend income distributable to shareholders or, equivalently, reducing the present value of taxes levied on income from capital. Vice versa, a reduction in the tax allowance on capital spending has the opposite effect of increasing the EMTR.

The focus of this paper is on the puzzling empirical evidence underpinning the evolution of the EMTR in the United States and the United Kingdom. Reforms of the corporate tax system in both countries since the early 1980s have been characterised by two well-known trends: the fall in the statutory corporate tax rate (SCTR) and the broadening of the corporate tax base brought about by the reduction of tax allowances on capital spending. The existing empirical evidence suggests that, as a result of these reforms, the EMTR on income from capital has considerably increased in both the United States and the United Kingdom over the period 1982-2005 regardless of the form of investment finance: in other words, the base-broadening effect, which increases the EMTR, has crowded out the rate-cut effect, which instead reduces the EMTR. ${ }^{3}$

This result is in clear contradiction with the traditional predictions of the corporate tax literature which states that the corporate tax burden should in-

\footnotetext{
${ }^{1}$ See Congressional Budget Office (2005, 2006), Ernst \& Young (2003), European Commission (1992, 2001), Institute for Fiscal Studies (2009), and OECD (1991, 2007).

${ }^{2}$ See Backus, Henriksen, and Storesletten (2008), Burnham and Ozanne (2006), De Mooij and Ederveen (2003), Devereux and Griffith (1998a), Devereux, Lockwood, and Redoano (2008), and Slemrod (1990).

${ }^{3}$ For an in-depth discussion of this evidence, see Devereux, Griffith and Klemm (2002).
} 
stead fall over time as a result of increasing international capital mobility and higher tax competition between countries. ${ }^{4}$ The notion that there is increasing competitive pressure on governments to reduce their corporation tax burdens finds increasing support in the recent empirical literature - see for example Garretsen and Peeters (2007) and Devereux, Lockwood, and Redoano (2008). The findings of this empirical literature are however entirely dependent on the choice of the variable used to proxy the tax burden. Notably all these studies employ the average effective tax rate (EATR) rather than the EMTR, on the ground that the former reflects firms' location decisions, while the latter is the appropriate indicator of the quantity of capital invested conditional on the choice of location. As EATRs appear to decline over time, see Devereux, Griffitth and Klemm (2002), it is clear that they are negatively correlated with any indicator of capital mobility. The reason however why EATRs appear to decline over time, while EMTRs do not, is merely technical: although both indicators express the impact of capital allowances on the effective tax burden as a proportion of the rate of return from investment, the EMTR uses at the denominator the marginal rate of return, while the EATR employs a rate of return higher than the marginal one. As a result, by assuming an arbitrary high rate of return, EATRs can hide away the negative effect of declining tax depreciation allowances, in turn resulting in a declining indicator of the tax burden.

This paper instead argues that the contradiction between theory and evidence on the EMTR arises because the standard neoclassical investment model employed for the measurement of the EMTR overstates the impact that variations of capital allowances have on the effective tax burden, since it omits constraints on earnings faced by firms investing in the United States and the United Kingdom. In fact, any tax saving generated by the deferred tax liability resulting from higher capital allowances only leads to a temporary difference between the tax and economic assessments of profits, and accounting rules in both countries prevent its distribution to shareholders. To this end, financial constraints on dividend policy are imposed to prevent firms from distributing any cash-flow arising from the tax saving generated by capital allowances. Therefore, for tax policy analysis, capital allowances and financial constraints on dividend policy must be taken into account simultaneously when measuring the effective tax burden on income from capital. ${ }^{5}$

A preliminary investigation on the importance of financial constraints in the measurement of the effective tax burden is offered by Polito (2009), who uses a generic neoclassical investment model for domestic investment financed by retained earnings to demonstrate that omission of financial constraints on dividend policy is bound to considerably understate any measure of the effective tax burden on income from capital, consequently leading to an incorrect assessment

\footnotetext{
${ }^{4}$ For a survey of this literature, see Wilson (1999) and Fuest, Huber and Mintz (2005).

${ }^{5}$ The importance of considering the effect of dividend policy constraints for tax policy analysis has already been pointed out in the economic literature. See, for example, Alworth (1979), Boadway and Bruce (1979), Bordignon, Giannini and Panteghini (1999), Kanniainen and Södersten (1994, 1995), King (1974), Sinn (1987) and Sørensen (1995).
} 
of the true impact of capital income taxation on investment choices.

This paper contributes to this line of research in three ways. First, financial constraints on dividend policy are applied to the extension of the King and Fullerton (1984) methodology recently proposed by Devereux and Griffith (1998b, 2003). The Devereux-Griffith model is chosen because it represents the latest and most comprehensive approach for the measurement of EMTRs; it provides a simple analytical framework which can be promptly implemented for empirical analysis; and it is widely used and accepted by policy-makers and academics. Second, the measurement of the EMTR is extended in this paper to the case of domestic investment financed by new equity and debt, rather than considering retained earnings as the only source of finance, as in Polito (2009). The third - and most important - novel contribution of the paper is empirical, as the new analytical framework is then employed to re-calculate time series of EMTRs in both the United States and the United Kingdom over the whole period 1982-2005.

The findings of the paper are as follows. The revised measures of the EMTRs show indeed that, once financial constraints on dividend policy are incorporated into the model, the dynamic evolution of the EMTRs in the United States and the United Kingdom is considerably different from that derived by the standard approach and it varies according to the form of investment finance: it has declined over time - as predicted by the corporate tax literature - on investment financed by either retained earnings or new equity, while it has remained relatively stable in the case of debt-financed investment. Most importantly, there is no evidence of increasing tax burden. Consequently, once averaged across the three forms of finance, EMTRs show a declining trend as EATRs, in turn suggesting that they are also indicators of the tax burden consistent with the hypothesis that increasing tax competition has indeed resulted in a lower tax burden over time.

The paper proceeds as follows. The next section reviews corporate tax reforms and discusses the existing empirical evidence on the evolution of the EMTR on income from capital in both the United States and the United Kingdom over the last two decades. This section also provides a non-technical description of how financial constraints on dividend policy work in practice and their implications for the measurement of the EMTR. Section 3 briefly outlines the logic underpinning the derivation of the EMTR on income from capital in the neoclassical investment theory, while Section 4 shows how the EMTR is computed using the Devereux and Griffith (1998b, 2003) approach. These measures of the EMTR are then compared and contrasted against those obtained from the constrained model, which is described in Section 5. Section 6 presents the new empirical evidence and shows the importance, from a quantitative point of view, of incorporating financial constraints on dividend policy into the neoclassical model. Section 7 concludes summarising the main findings and reflects on the implications of this work for tax policy analysis. 


\section{Existing empirical evidence and beyond}

Reforms of the corporate tax system in the United States and the United Kingdom since the early 1980s have been characterised by two well-known trends: the fall in the SCTR and the broadening of the corporate tax base brought about by the reduction of tax allowances on capital spending. ${ }^{6}$ All data on the evolution of the EMTRs in the United States, the United Kingdom and 17 other OECD countries over the period 1982-2001 are available through Devereux, Griffith and Klemm (2002), who use this information to assess the impact of corporate tax reforms on the EMTR over this period of time. However, their analysis focuses on the average EMTR across the 19 countries, without explicitly disclosing the dynamic evolution of the EMTR in each individual country of the sample. This paper therefore focuses on the evolution EMTRs in the United States and the United Kingdom and extends the analysis up to 2005 using data from the International Tax Database of the Institute for Fiscal Studies. ${ }^{7}$

Figure 1 shows that in the United States the SCTR has fallen from 50 per cent in 1982 to 39 per cent in 2005 while, over the same period of time, the gradual reduction of capital allowances has resulted in the fall of the present discounted value (PDV) of capital allowances per unit of capital expenditure in plant and machinery from 87 to 79 per cent. ${ }^{8}$ Figure 2 shows that similar patterns are observed for the United Kingdom over the same period of time: the SCTR has fallen considerably from 52 to 30 per cent, whereas the reduction of capital allowances has resulted in a decrease in the PDV of capital allowances for investment in plant and machinery from 100 to 73 per cent. ${ }^{9}$ The two figures also show that this trend of falling capital allowances has only been temporarily interrupted during periods of economic recession: allowances on capital spending were high in the early 1980s in both countries, and were temporarily increased in the early 2000 in the United States and in the early 1990s in the United Kingdom.

The impact of these reforms on the EMTR measured in the two countries for domestic investment in plant and machinery financed by either retained earnings or new equity is presented in Figures 3 and 4 respectively. ${ }^{10}$ In both countries the EMTR is below the SCTR because tax allowances on capital spending on plant and machinery have persistently exceeded the corresponding rate of economic depreciation. However, the base-broadening effect resulting from the reduction

\footnotetext{
${ }^{6}$ Rate-cutting and base-broadening reforms of the corporate tax system do not characterise the United States and the United Kingdom alone, but are part of a more general trend observed across the whole OECD area. For a recent survey, see OECD (2007).

${ }^{7}$ This database is available online at http://www.ifs.org.uk.

${ }^{8}$ The PDV of capital allowances increases with the rate of capital allowance, and ranges from 0 to 100 per cent. When the tax code does not grant any allowance on capital spending, then the PDV of capital allowances is zero. In contrast, the PDV is 100 per cent when the tax code allows firms to deduct the entire cost of capital immediately.

${ }^{9}$ Capital allowances have also declined considerably in both countries for investment in industrial buildings. See Devereux, Griffith and Klemm (2002).

${ }^{10}$ The EMTR is computed without considering taxation at shareholder level. For this reason, the EMTR on domestic investment financed by retained earnings equals the EMTR on the same type of investment financed by new equity. See Devereux and Griffith (1998b).
} 
of capital allowances has dominated the rate-cut effect, thus causing the EMTR to increase over the period 1982-2005, from 22 to 24 per cent in the United States and from 0 to 20 per cent in the United Kingdom.

Figures 5 and 6 plot the evolution of the EMTR for domestic investment financed by debt. The EMTR under debt finance is well below zero in both countries. This is because the EMTR on income from capital is equal to zero when firms can deduct the cost of capital entirely (as in the case of debt finance) and the tax allowance for capital spending reflects the true economic depreciation. Consequently, the EMTR becomes negative when the capital allowance is larger than the rate of depreciation, meaning that the tax code is indeed granting an investment subsidy to firms. ${ }^{11}$ Over the period 1982-2005, however, the base broadening effect due to the reduction of capital allowances has reduced the extent of this subsidy effect, in turn resulting in the EMTR increasing from -94 to -46 per cent in the United States and from -72 to -32 per cent in the United Kingdom.

The evidence presented so far clearly raises two important questions: first, the economic literature on corporate tax competition suggests that high international capital mobility, coupled with increasing tax competition between governments to attract new investment, should lead to a fall in the tax burden on income from capital. However, this prediction clearly contradicts the empirical evidence which appears to suggest that, rather than falling, EMTRs on income from capital have been increasing over time. The second question raised by this evidence refers to the rationale underpinning the observed corporate tax policy reforms: if governments are eager to attract new capital by providing a low-tax environment to investors, why would they offset the benefit from lower tax rates by broadening the corporate tax base?

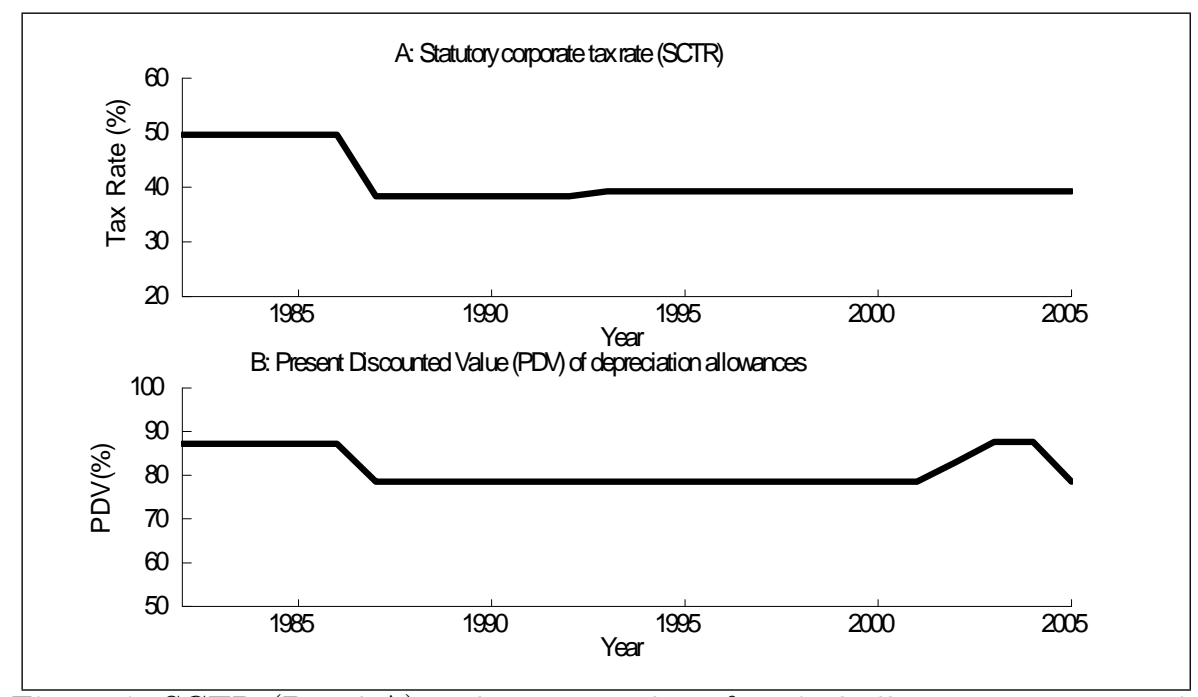

Figure 1: SCTR (Panel A) and present value of capital allowances on one unit

\footnotetext{
${ }^{11}$ See Atkinson and Stiglitz (1980) and Devereux and Griffith (1998b).
} 
of investment in plant and machinery (Panel B) in the United States from 1982 to 2005. Sources: Devereux, Griffith and Klemm (2002) and IFS International Tax Database.

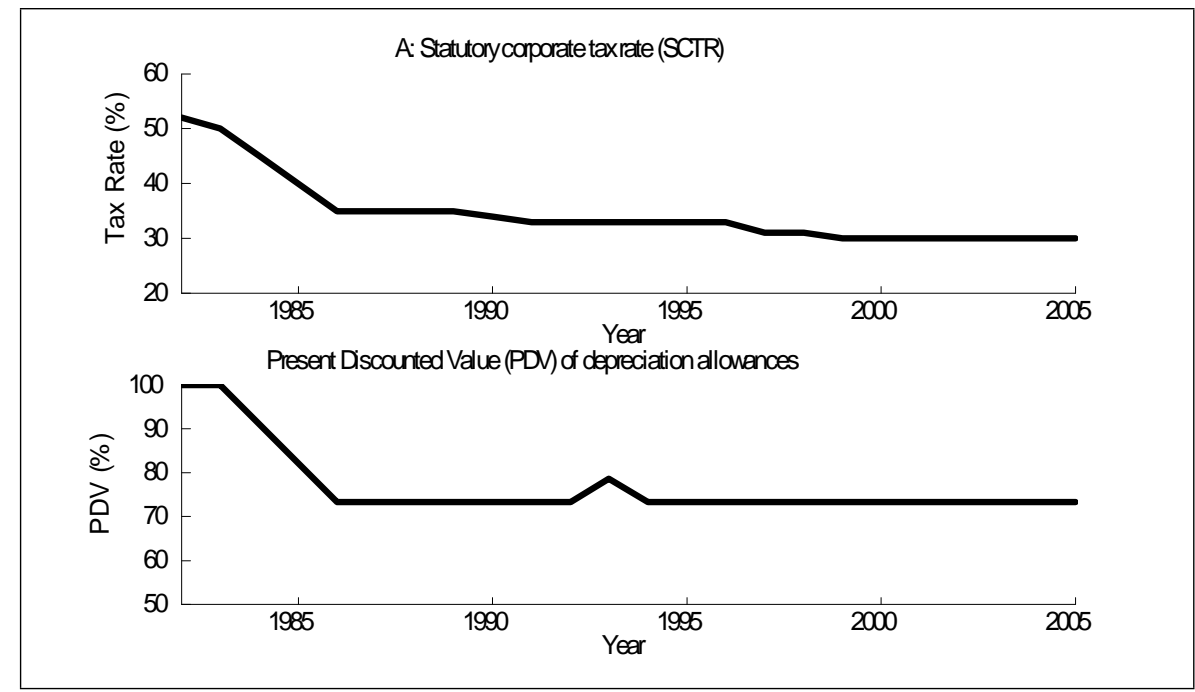

Figure 2: SCTR (Panel A) and present value of capital allowances on one unit of investment in plant and machinery (Panel B) in the United Kingdom from 1982 to 2005. Sources: Devereux, Griffith and Klemm (2002) and IFS International Tax Database.

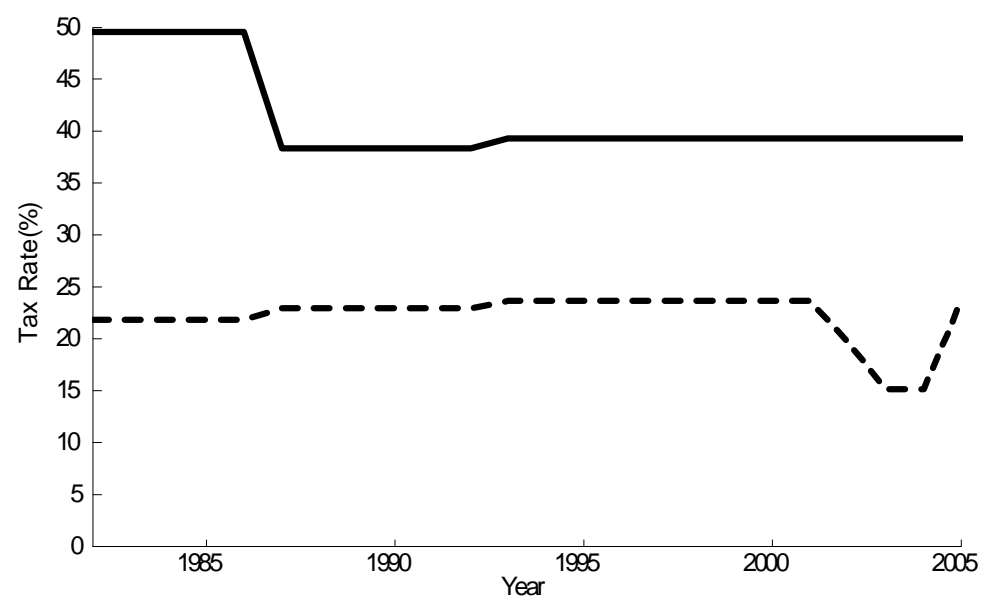

Figure 3: SCTR ( - ) and EMTR ( - - ) on domestic investment in plant and machinery financed by retained earnings in the United States from 1982 to 2005. Taxation at shareholder level is not included. Sources: Devereux, Griffith and Klemm (2002) and IFS International Tax Database. 


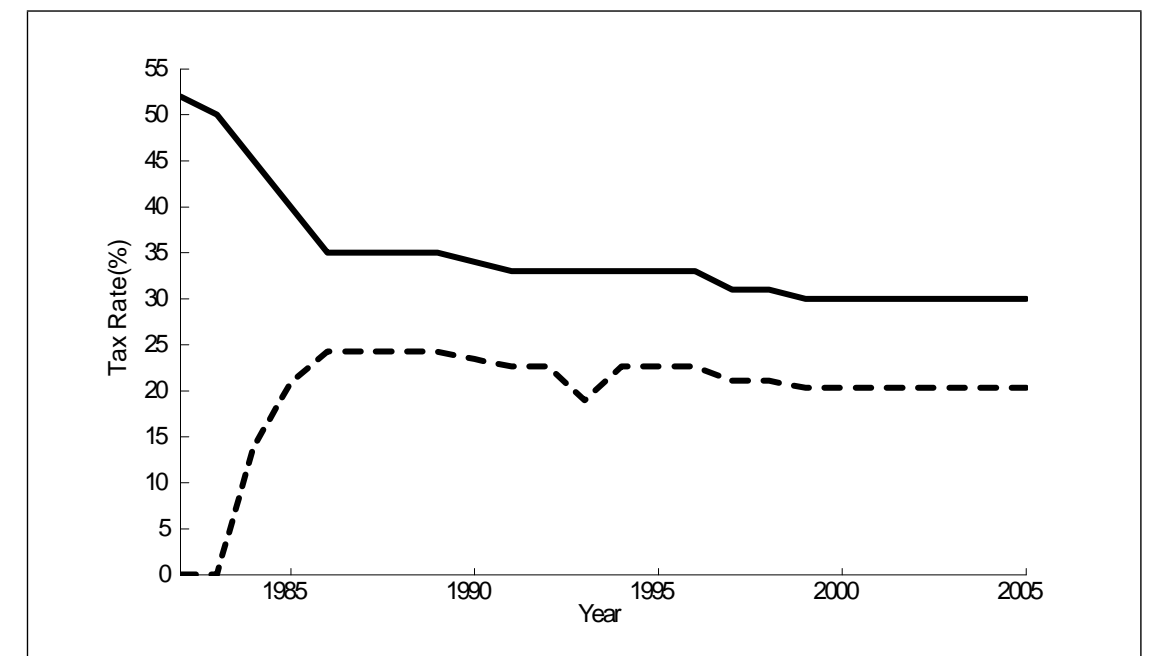

Figure 4: SCTR ( - ) and EMTR ( - - - ) on domestic investment in plant and machinery financed by retained earnings in the United Kingdom from 1982 to 2005. Taxation at shareholder level is not included. Sources: Devereux, Griffith and Klemm (2002) and IFS International Tax Database.

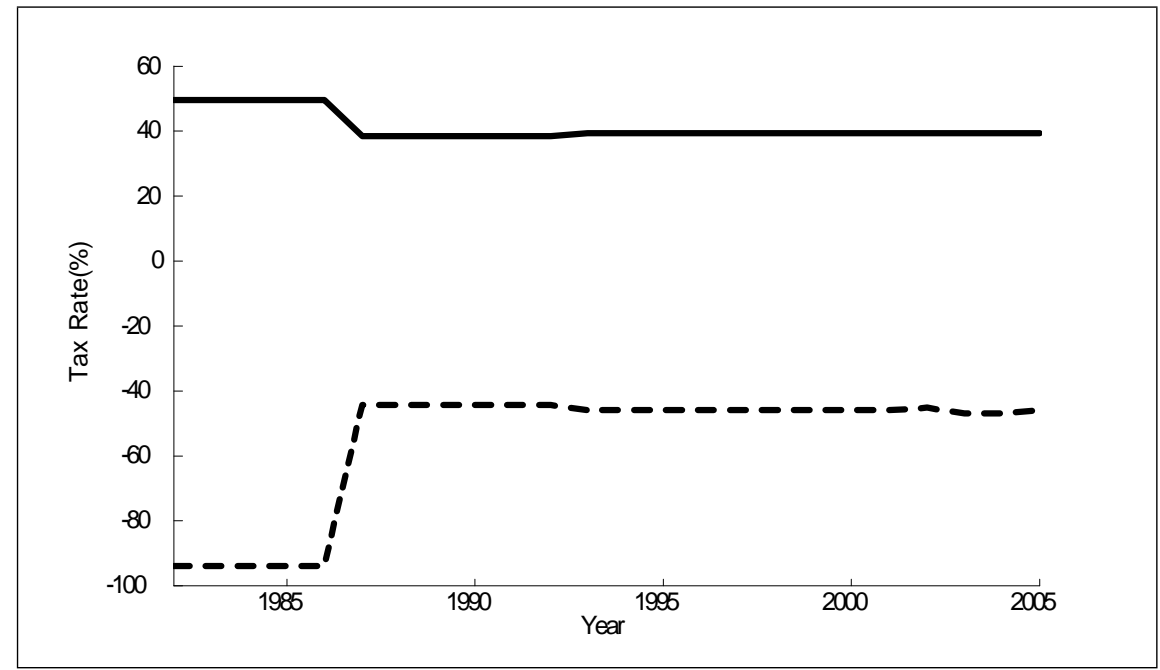

Figure 5: SCTR ( - ) and EMTR ( - - ) on domestic investment in plant and machinery financed by debt in the United States from 1982 to 2005.

Taxation at shareholder level is not included. Sources: Devereux, Griffith and Klemm (2002) and IFS International Tax Database. 


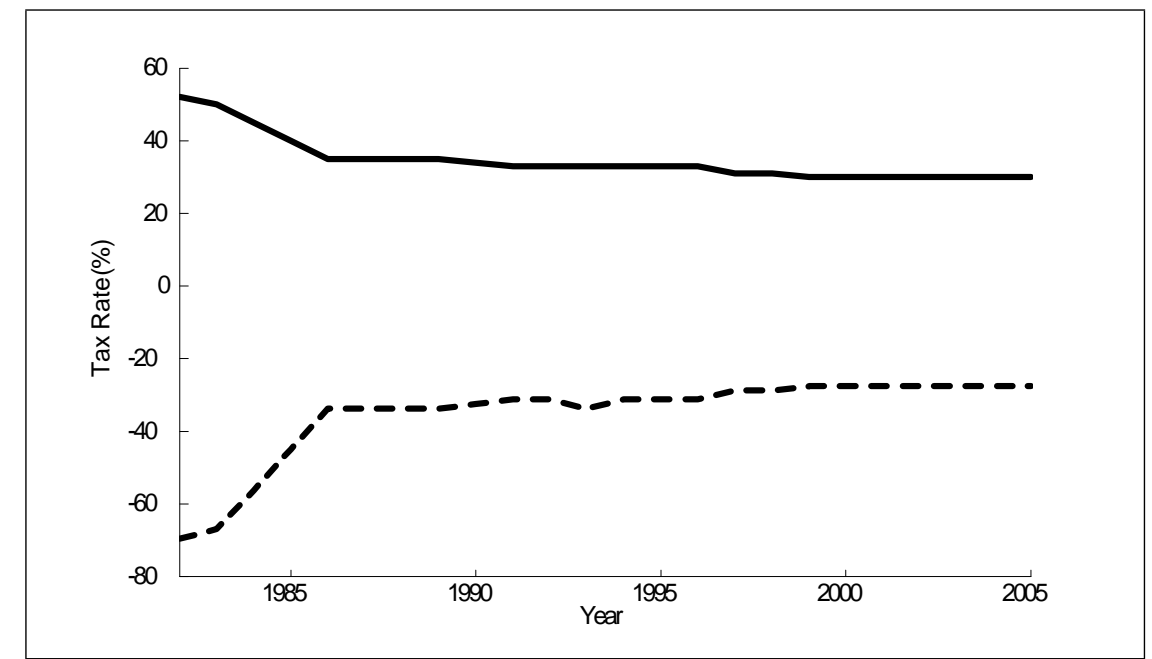

Figure 6: SCTR ( - ) and EMTR ( - - ) on domestic investment in plant and machinery financed by debt in the United Kingdom from 1982 to 2005.

Taxation at shareholder level is not included. Sources: Devereux, Griffith and Klemm (2002) and IFS International Tax Database.

This paper argues that the proposition that high capital mobility should reduce the effective tax burden on income from capital is indeed backed by the data: the problem lies instead with the empirical evidence used in the literature, which is drawn from an incorrect interpretation of how changes in the tax base, caused by a reduction in capital allowances, impact on the effective tax burden on income from capital within the neoclassical investment model.

To clarify this point, note that the EMTR ultimately measures the tax burden on the return from the marginal unit of investment, as measured by the present value of dividends distributable to shareholders. According to the traditional corporate tax literature, a reduction in the statutory tax rate raises the present value of dividends distributable to shareholders, in turn increasing the after-tax marginal rate of return, thus reducing the EMTR. On the other hand, for any given statutory tax rate, a reduction in the capital allowance increases the tax base, hence reducing the present value of dividends distributable to shareholders, thus leading to a higher EMTR. This widely accepted view of how changes in the tax allowance on capital spending affect a firm's incentive to invest is, however, misleading. This is because governments do not grant higher allowances on capital spending to increase dividend payments to shareholders. Instead, capital allowances are granted to provide firms with extra sources of internal investment funding. This is ultimately a financial tax incentive. The incentive takes the form of deferred taxation and results only in a temporary difference between the tax and economic assessments of profits. Of course, firms could use the extra funding arising from capital allowances to increase dividend pay-outs rather than make new investments. This elusive behaviour is however not possible in practice since any firm investing in the United States and the 
United Kingdom must comply with accounting standards which require them to set full provision for deferred tax assets or liabilities arising from any temporary differences between the tax and economic assessments of profits. ${ }^{12}$

To illustrate how the financial constraint works in practice, consider a firm purchasing one unit of physical capital which generates a gross income of 100 dollars. Suppose the value of economic depreciation equals 10 dollars. Hence the firm's profit is 90 dollars. Suppose the corporate income tax rate is 30 per cent and the tax code allows the firm to claim a capital allowance worth 20 dollars. Under an unconstrained model the tax base is 80 dollars, the firm pays 24 dollars in taxes and it is free to distribute to shareholders the remaining 66 dollars. Accounting standards require the firm to set a provision for deferred taxes amounting to 3 dollars, equal to the tax on the difference between the tax allowance and the value of depreciation. This is recorded in the company accounts as a deferred tax. Therefore, the total tax liability is 27 dollars, as a result of the sum of current and deferred taxes, and the firm can distribute only 63 dollars to shareholders. If the firms keeps the resources constrained in provisions for deferred taxes in a bank account which pays a 10 per cent interest rate, then dividend income distributable to shareholders rises to 63.3 dollars.

This numerical example shows that the accounting standards result in a constraint on dividend policy which almost entirely prevents firms from distributing dividends to shareholders out of higher tax allowances on capital spending. According to the neoclassical corporate tax literature, an increase in the allowance on capital spending should reduce dividend income: in practice, as shown in the example, an increase in the allowance has little effect on the dividend pay-out.

The example also clarifies three key implications of this paper for tax policy and empirical analyses. First, existing measures of the EMTR, which omits financial constraints on dividend policy, largely overstate the impact of capital allowances on the effective tax burden on income from capital. Second, since variations in capital allowances have little effect on dividend policy, there is no contradiction in the rationale underpinning rate-cutting and base-broadening reforms observed in the United States and the United Kingdom since the early 1980s. Third, as it is shown in the rest of the paper, after incorporating financial constraints on dividend policy into the model, the EMTR on income from capital closely follows the declining dynamic of the SCTR. Therefore, any empirical research on the impact of corporate taxation on the international allocation of capital which is based on the existing measures of the EMTR is bound to employ a highly mis-specified time series of the effective tax burden on income from capital.

\footnotetext{
${ }^{12}$ This principle is essentially encompassed by modern accounting standards. Under International Financial Reporting Standards, deferred tax should be accounted for using the principles in IAS 12: Income Taxes, which is similar (but not identical) to SFAS 109 under US GAAP. Both these accounting standards require a temporary difference approach as described in the text.
} 


\section{Neoclassical investment theory and the EMTR on income from capital}

The standard neoclassical investment model underpinning the computation of the EMTR considers a competitive firm seeking to maximise its shareholders' wealth, $W_{0}$, while facing a perfectly elastic supply of capital and a frictionless capital market, where it can borrow and lend at the constant nominal interest rate $i$. Investment choices are riskless and taken in the absence of bankruptcy costs. The objective function of the firm is generally formulated as

$$
W_{0}=\sum_{t=0}^{\infty} \frac{\gamma \Delta D_{t}-\Delta N_{t}}{(1+\rho)^{t}}
$$

where $\Delta D_{t}$ denotes the change in dividend income in period $t, \Delta N_{t}$ is the change in new equity issues in period $t, \gamma$ is the after-tax income received by shareholders for any unit increase in dividend income, and $\rho$ is the shareholders' discount rate. In particular, $\gamma=\left(1-m^{d}\right) /(1-z)(1-c)$, where $m^{d}, z$ and $c$ measure the personal tax rates on dividend income, capital gain and the imputation rate, respectively; whereas $\rho=i\left(1-m^{i}\right) /(1-z)$, with $m^{i}$ denoting the personal tax rate on interest income.

Dividend income is computed in any period $t$ from the identity between sources and uses of funds

$$
\Delta B_{t}+N_{t}+Q_{t}\left(K_{t-1}\right)-i B_{t-1}=D_{t}+I_{t}+T_{t},
$$

where $\Delta B_{t}$ denotes the change in the stock of debt in period $t, Q_{t}\left(K_{t-1}\right)$ is output in period $t$ depending on the stock of capital in the previous period, $K_{t-1}, i B_{t-1}$ measures interest payments on the outstanding stock of debt, $I_{t}$ is new investment undertaken in period $t$, and $T_{t}$ measures the period $t$ corporate tax liability. ${ }^{13}$ The capital stock evolves according to the capital accumulation equation

$$
K_{t}=(1-\delta) K_{t-1}+I_{t},
$$

where $\delta$ is the rate of physical depreciation of the capital stock. The corporate tax literature typically formulates the tax function as

$$
T_{t}=\tau\left[Q_{t}\left(K_{t-1}\right)-i B_{t-1}-\phi\left(I_{t}+K_{t-1}^{T}\right)\right],
$$

where $\tau$ is the statutory tax rate, $\phi$ is the tax allowance on capital spending, and $K_{t-1}^{T}$ is the tax-written-down value of the capital stock at the end of period $t$, which evolves according to

$$
K_{t}^{T}=(1-\phi) K_{t-1}^{T}+I_{t} .
$$

\footnotetext{
${ }^{13} Q_{t}($.$) denotes a standard neoclassical production function, continuos and twice differen-$ tiable, with positive first derivative and negative second derivative, and satisfying the Inada conditions.
} 
Following Jorgenson (1963) and Hall and Jorgenson (1967), the after-tax user cost of capital, $\tilde{p}$, is calculated by maximising wealth in equation (1), subject to the

constraints in equations (2) to (5). The EMTR, which summarises the impact of taxes on the marginal return from investment, is then defined as the difference between the user cost of capital after and before taxes, measured as a proportion of the after-tax user cost of capital:

$$
E M T R_{j, k}=\frac{\tilde{p}_{j, k}-r}{\tilde{p}_{j, k}}=1-\frac{r}{\tilde{p}_{j, k}},
$$

where $r$ measures the marginal rate of return in the absence of taxes, the subscript $j=U, C$ indicates that the computation is carried out from the "unconstrained" and "constrained" models respectively, while the subscript $k=$ $R E, N E, B \quad$ distinguishes between three traditional forms of investment finance considered in the corporate tax literature: retained earnings $(R E)$, new equity issues $(N E)$ and debt $(B)$. Equation (6) shows that any tax measure that increases (reduces) the user cost of capital has the effect of increasing (decreasing) the EMTR on income from capital. For this reason, hereafter the analysis will focus only on the impact that the tax system has on the user cost of capital.

\section{Unconstrained EMTR}

To explicitly compute the user cost of capital this paper follows the approach recently proposed by Devereux and Griffith (1998b, 2003). The essential idea behind this approach is to determine the user cost of capital from a temporary perturbation of the capital stock: the firm purchases one unit of capital in period $t$ and reduces investment in period $t+1$ by $(1-\delta)(1+\pi)$ where $\pi$ is the inflation rate from $t$ to $t+1$. The temporary increase in the capital stock yields a return in period $t+1$ equal to $\left(\tilde{p}_{U, k}+\delta\right)(1+\pi)$, where $\tilde{p}_{U, k}$ denotes the marginal rate of return previously defined with $k=R E, N E, B$. In the absence of taxes, $\tilde{p}_{U, k}=r$, where $r$ is the real rate of return determined from the Fisher equation $(1+i)=(1+r)(1+\pi)$. As pointed out above, the effect of corporate income taxation on investment choices is summarised by the impact that the tax code has on the user cost of capital, which in turn depends on the type of investment finance. The general formulation of the after-tax user cost of capital for domestic investment is therefore given by

$$
\tilde{p}_{U, k}=\frac{\left(1-A_{\phi}\right)[\rho+\delta(1+\pi)-\pi]}{(1+\pi)(1-\tau)}-\frac{F_{U, k}(1+\rho)}{\gamma(1+\pi)(1-\tau)}-\delta,
$$

where $A_{\phi}$ is the tax saving on the PDV of tax allowances on capital spending, granted at the rate $\phi$, and $F_{U, k}$, with $k=R E, N E, B$, measures the impact of alternative forms of finance on the user cost of capital. In particular, it follows 
that

$$
\begin{aligned}
F_{U, R E} & =0 \\
F_{U, N E} & =-\rho \frac{(1-\gamma)(1-\tau \phi)}{1+\rho} \\
F_{U, B} & =\gamma \frac{(1-\tau \phi)[\rho-i(1-\tau)]}{1+\rho}
\end{aligned}
$$

when investment is financed by retained earnings, new equity issues and debt respectively.

Equations (7) and (10) can be employed to determine the impact of changes in the tax allowance on capital spending on the user cost of capital, hence the EMTR. To this end, consider a tax code granting the capital allowance $\phi$ on a declining balance basis, then

$$
A_{\phi}=\tau \phi \sum_{s=0}^{\infty}\left(\frac{1-\phi}{1+\rho}\right)^{s}=\tau \phi \frac{(1+\rho)}{\rho+\phi},
$$

which shows that an increase in the capital allowance rate raises the PDV of tax allowances on capital spending since

$$
\frac{\partial A_{\phi}}{\partial \phi}=\tau \frac{(1+\rho) \rho}{(\rho+\phi)^{2}}>0 .
$$

Using these results, it is straightforward to show that the effect of an increase of the capital allowance rate on the user cost of capital under the three forms of finance is given by

$$
\begin{aligned}
\frac{\partial \tilde{p}_{U, R E}}{\partial \phi} & =-\frac{[\rho+\delta(1+\pi)-\pi]}{(1+\pi)(1-\tau)} \frac{\partial A_{\phi}}{\partial \phi} \\
\frac{\partial \tilde{p}_{U, N E}}{\partial \phi} & =\frac{\partial \tilde{p}_{U, R E}}{\partial \phi}-\frac{\rho \tau(1-\gamma)}{\gamma(1+\pi)(1-\tau)}, \\
\frac{\partial \tilde{p}_{U, B}}{\partial \phi} & =\frac{\partial \tilde{p}_{U, R E}}{\partial \phi}+\frac{\tau[\rho-i(1-\tau)]}{(1+\pi)(1-\tau)} .
\end{aligned}
$$

In essence, the unconstrained model predicts that a reduction in the capital allowance always increases the EMTR on domestic investment financed by retained earnings. This also applies when investment is financed by new equity and dividend income is taxed more heavily than capital gains. The effect of reductions in the capital allowance on the EMTR when investment is financed by debt is in principle ambiguous: on the one hand, the lower capital allowance increases the retained earnings component of the user cost of capital, as computed by the first term on the right-hand side of equation (14), while on the other hand it increases the benefit from debt financing, as measured by the last term in equation (14). 


\section{Constrained EMTR}

This section introduces financial constraints on dividend policy faced by firms investing in the United States and the United Kingdom into the Devereux and Griffith (1998b, 2003) formulae of the user cost of capital. As described in Section 2, financial constraints on dividend policy require firms to set in any period $t$ a provision for deferred taxes, equal to the tax rate on the difference between the capital allowance and economic depreciation, namely $\tau\left(\phi K_{t}^{T}-\delta K_{t}\right)$. This implies that dividend income in any period $t$ cannot exceed the after-tax profit, reduced by the tax rate on the difference between the capital allowance and the depreciation rate. Notice that under the accounting standards followed by firms investing in both the United States and the United Kingdom, provision for deferred taxes are measured on the difference between accounting and tax depreciation, whereas the above definition of the period $t$ provision for deferred taxes assumes that economic depreciation equals accounting depreciation. We retain this assumption on that basis that it is consistent with the standard conventions in the established literature on tax policy and financial constraints - see previously cited papers by Boadway and Bruce (1979), Kanniainen and Södersten (1994 and 1995), King (1974), Sørensen (1995) - and also taking into account the fact that over the past 20 years accounting standards followed by United States and United Kingdom companies have increased their flexibility in order to align accounting depreciation to economic depreciation. Indeed, the IAS 16 (International GAAP 2010) does not prescribe any specific method and/or rate of depreciation for accounting purposes, as it requires the depreciation charge to reflect the pattern of consumption of the benefits the assets brings over its useful life, which is essentially consistent with economic depreciation.

As stated by Kanniainen and Södersten (1995), the positive (negative) temporary difference between the capital allowance and the rate of depreciation represents a deferred tax liability (asset) which must be retained by the firm rather than be distributed to shareholders. In principle, the constrained liquidity should be used to carry out new investment. However, this would be in conflict with the model assumption of a one-unit increase in capital in period $t$ and constant capital stock starting from $t+1$. As a result, following Polito (2009), financial resources constrained in provisions for deferred taxes represent an excess of liquidity that firms can only invest in the capital markets. In turn, this implies that deferred taxation generates to shareholders a cash-flow equal to the after-tax rate of return on the resources constrained in provisions for deferred taxes.

There are several equivalent ways of incorporating financial constraints on dividend policy into the neoclassical investment model. King (1974) and Kanniainen and Södersten (1995) treat the dividend policy constraint just as an extra constraint in the maximisation problem of the firm. Polito (2009) shows that the financial constraint can also be incorporated into the neoclassical model by opportunely modifying the identity between sources and uses of funds. This paper instead introduces financial constraints into the model by specifying the total tax liability of the firm in any period $t, T_{t}$, as the sum of current and 
deferred taxes. In particular, the corporate tax function can be formulated as

$$
T_{t}=T_{t}^{c}+T_{t}^{d},
$$

where current taxes $T_{t}^{c}$ are defined as in equation (4), and $T_{t}^{d}$ denotes deferred taxes, which can be written as

$$
T_{t}^{d}=\tau\left(\phi K_{t}^{T}-\delta K_{t}\right),
$$

which shows that after accounting for deferred taxes a new source tax liability arises to shareholders in the form of undistributable tax savings. The formulation of the tax function in equations (15) and (16) is essentially consistent with how firms report their tax liability in their accounts, hence providing a very transparent way of disclosing the impact of the constraint on dividend policy. ${ }^{14}$ When using the definition of the tax function in equations (15) and (16), the user cost of capital on domestic investment under the dividend policy constraint is formulated as

$$
\tilde{p}_{C, k}=\frac{\left[1-A_{\phi}+\Delta-i\left(1-\tau^{i}\right) \Delta\right][\rho+\delta(1+\pi)-\pi]}{(1+\pi)(1-\tau)}-\frac{F_{C, k}(1+\rho)}{\gamma(1+\pi)(1-\tau)}-\delta,
$$

where $k=R E, N E, B ; \tau^{i}$ is the tax rate on financial income and

$$
\Delta=A_{\phi}-A_{\delta}=\tau i \frac{(1+i)(\phi-\delta)}{(i+\phi)(i+\delta)}
$$

is the present value of provisions for deferred taxes, with $A_{\delta}$ denoting the present value of depreciation. ${ }^{15}$ Note that $\Delta \gtreqless 0$ if $A_{\phi} \gtreqless A_{\delta}$, which holds as long as $\phi \gtreqless \delta$. The economic interpretation of equation (17) is provided below for each of the three forms of finance.

When investment is financed by retained earnings, $F_{C, R E}=0$ and the user cost of capital under the constrained model is written as

$$
\tilde{p}_{C, R E}=\tilde{p}_{U, R E}+\left[1-i\left(1-\tau^{i}\right)\right] \frac{[\rho+\delta(1+\pi)-\pi]}{(1+\pi)(1-\tau)} \Delta,
$$

where $\tilde{p}_{U, R E}$ is the user cost of capital on investment financed by retained earnings obtained from the unconstrained model obtained after replacing (8) into (7). Equation (18) shows that the financial constraint adds two terms to the user cost of capital derived from the unconstrained model: the first term, $\frac{[\rho+\delta(1+\pi)-\pi]}{(1+\pi)(1-\tau)} \Delta$, measures the increase in the user cost of capital in terms of foregone dividend caused by the accumulation of provisions for deferred taxes. The second term, $-i\left(1-\tau^{i}\right) \frac{[\rho+\delta(1+\pi)-\pi]}{(1+\pi)(1-\tau)} \Delta$, measures the reduction in the user cost of

capital due to the investment in the capital markets of resources accumulated in

\footnotetext{
${ }^{14}$ For a detailed description of the rules for recording temporary differences in a company's financial statement, see Alexander and Archer (2009).

${ }^{15} A_{\delta}$ is measured by replacing $\phi$ with $\delta$ in equation (11).
} 
provisions for deferred taxes. In addition, equation (18) shows that $\tilde{p}_{C, R E}>$ $\tilde{p}_{U, R E}$ as long as $\phi>\delta$ : in other words, whenever the tax code grants a financial tax incentive $(\phi>\delta)$, the EMTR on domestic investment, after correctly accounting for deferred taxes, is always greater than the EMTR computed from the unconstrained model. Differentiation of (18) with respect to the capital allowance leads to

$$
\begin{aligned}
\frac{\partial \tilde{p}_{C, R E}}{\partial \phi} & =\frac{\partial \tilde{p}_{U, R E}}{\partial \phi}+\left[1-i\left(1-\tau^{i}\right)\right] \frac{[\rho+\delta(1+\pi)-\pi]}{(1+\pi)(1-\tau)} \frac{\partial A_{\phi}}{\partial \phi} \\
& =i\left(1-\tau^{i}\right) \frac{\partial \tilde{p}_{U, R E}}{\partial \phi} .
\end{aligned}
$$

Equation ((19)) shows that an increase in the tax allowance on capital spending has a limited impact (only a fraction $i\left(1-\tau^{i}\right)$ of the effect predicted by the unconstrained model) on the user cost of capital and the EMTR. Therefore, the results in equations (18) and (19) show that whenever the tax code grants a financial tax incentive, omission of the financial constraint associated with deferred taxation is bound to understate the true measure of the user cost of capital and the EMTR, as well as overstating the impact that changes in the capital allowance have on the incentive to invest.

When investment is financed by new equity, in period $t$ the firm receives a tax allowance $\tau \phi$ but has to set a provision for deferred taxes of $\tau(\phi-\delta)$. This amount of resources is invested in the capital markets and generates an after-tax return $i\left(1-\tau^{i}\right) \tau(\phi-\delta)$. Hence, the net amount of new equity raised is $(1-\tau \delta)-i\left(1-\tau^{i}\right) \tau(\phi-\delta)$. Since funds are used to repurchase this amount of new equity in period $t+1$, then the shareholder receives a similar amount in period $t+1$ as a repurchase of equity. Combining these effects, the user cost of capital on domestic investment financed by new equity under the constrained model is formulated as

$$
\tilde{p}_{C, N E}=\tilde{p}_{C, R E}-\frac{F_{C, N E}(1+\rho)}{\gamma(1+\pi)(1-\tau)},
$$

where

$$
F_{C, N E}=F_{U, N E}-\frac{\rho \tau(1-\gamma)\left[(\phi-\delta)-i\left(1-\tau^{i}\right)(\phi-\delta)\right]}{1+\rho} .
$$

Equations (20) and (21) show that the impact of the financial constraint on the user cost of capital and the EMTR ultimately depends on the taxation of dividend income relative to capital gains: if the tax code grants a financial tax incentive $(\phi>\delta)$, then omission of the financial constraint leads to the understatement (overstatement) of the user cost of capital and the EMTR when dividend income is taxed more (less) than capital gains. In addition, equation 
(21) implies that

$$
\begin{aligned}
\frac{\partial F_{C, N E}}{\partial \phi} & =\frac{\partial F_{U, N E}}{\partial \phi}-\frac{\rho \tau(1-\gamma)}{1+\rho}+\frac{i\left(1-\tau^{i}\right) \rho \tau(1-\gamma)}{1+\rho} \\
& =i\left(1-\tau^{i}\right) \frac{\partial F_{U, N E}}{\partial \phi}
\end{aligned}
$$

which shows that changes in the tax allowance on capital spending have an effect on the new equity component of the user cost of capital considerably smaller than that predicted by the unconstrained model. Likewise, it follows that

$$
\begin{aligned}
\frac{\partial \tilde{p}_{C, N E}}{\partial \phi} & =\frac{\partial \tilde{p}_{C, R E}}{\partial \phi}-\frac{\partial F_{C, N E}}{\partial \phi} \frac{(1+\rho)}{\gamma(1+\pi)(1-\tau)} \\
& =i\left(1-\tau^{i}\right) \frac{\partial \tilde{p}_{U, N E}}{\partial \phi},
\end{aligned}
$$

with $\tilde{p}_{U, N E}$ denoting the user cost of capital on investment financed by new equity obtained from the unconstrained model after replacing (9) into (7), which shows that the user cost of capital and the EMTR also respond to changes in the tax allowance on capital spending much less than predicted by the standard theory when investment is financed by new equity.

Finally, when investment is financed by debt shareholders in period $t$ do not have to give up dividend income worth $(1-\tau \delta)-i\left(1-\tau^{i}\right) \tau(\phi-\delta)$. Instead the firm borrows this amount. In period $t+1$, the firm must repay the debt with interest, and this results in a reduction of shareholders' cash-flow of $\left[(1-\tau \delta)-i\left(1-\tau^{i}\right) \tau(\phi-\delta)\right][1+i(1-\tau)]$. Combining these effects, the user cost of capital on debt-financed investment can be formulated as

$$
\tilde{p}_{C, B}=\tilde{p}_{C, R E}-\frac{F_{C, B}(1+\rho)}{\gamma(1+\pi)(1-\tau)},
$$

where

$$
F_{C, B}=F_{U, B}+\tau(\phi-\delta) \frac{\gamma[\rho-i(1-\tau)]}{1+\rho}-i\left(1-\tau^{i}\right) \tau(\phi-\delta) \frac{\gamma[\rho-i(1-\tau)]}{1+\rho} .
$$

Equation (23) shows that debt financing provides an even greater incentive on the marginal choice to invest than predicted by the unconstrained model. This is because, as argued by Kanniainen and Södersten (1995), resources constrained in provisions for deferred taxes represent an interest-free loan from the government: hence, firms financing investment by debt can exploit this interest-free borrowing opportunity, as measured by the second term on the right-hand side of equation (23). As for the case of new equity finance, it is straightforward to show that a change in the capital allowance has a much smaller effect on the debt component of the user cost of capital than that predicted under the standard theory since

$$
\frac{\partial F_{C, B}}{\partial \phi}=-i\left(1-\tau^{i}\right) \frac{\tau \gamma[\rho-i(1-\tau)]}{1+\rho}=-i(1-\tau) \frac{\partial F_{U, B}}{\partial \phi} .
$$


Consequently, also in the case of domestic investment financed by debt, the impact of variations in the tax allowances on capital spending in the constrained model is much smaller than that predicted by the unconstrained model since:

$$
\begin{aligned}
\frac{\partial \tilde{p}_{C, B}}{\partial \phi} & =i\left(1-\tau^{i}\right) \frac{\partial \tilde{p}_{U, R E}}{\partial \phi}+i\left(1-\tau^{i}\right) \frac{\partial F_{U, B}}{\partial \phi} \frac{(1+\rho)}{\gamma(1+\pi)(1-\tau)} \\
& =i\left(1-\tau^{i}\right) \frac{\partial \tilde{p}_{U, B}}{\partial \phi}
\end{aligned}
$$

where $\tilde{p}_{U, B}$ is the user cost of capital on investment financed by debt obtained from the unconstrained model after replacing (10) into (7).

To summarise, this section has demonstrated analytically that, after correctly accounting for deferred taxation, a reduction in the tax allowance on capital spending has a considerably smaller effect on the EMTR on income from capital than predicted by the unconstrained model. This results holds regardless of the form of investment finance. This results also holds regardless how firms distribute earnings to shareholders. In the context of the neoclassical model used in this paper, deferred taxation acts as a constraint on dividend distribution because earnings are transferred to shareholders though dividends. However, the constraint works under any other form of earnings distribution: as shown in equation (16), accounting rules reclassify part of earnings as future tax liabilities, hence reducing the overall value of the firm. Only the return on the investment of the deferred tax liability increases the value of the firm. In a sense, this is consistent with Modigliani-Miller view that only the rate of return generated by the firm matters, while the form of investment finance is irrelevant.

\section{Empirical evidence revisited}

This section provides a quantitative assessment of the analytical results discussed so far, by comparing and contrasting the development of EMTRs computed from the constrained and unconstrained models. All computations are carried out using tax data for the United States and the United Kingdom over the period 1982-2005 previously described and following Devereux, Griffith and Klemm (2002)'s calibration of the model, which considers only domestic investment in plant and machinery; does not include taxation at shareholder level; and assumes that plant and machinery depreciate at 12.25 per cent on a declining balance basis, the real interest rate is 10 per cent, and the inflation rate is 3.5 per cent.

Figures 7 and 8 plot, for the United States and the United Kingdom respectively, the evolution over the period 1982-2005 of the SCTR and of the EMTRs under both the constrained and unconstrained models when domestic investment is financed by retained earnings. Since the basic calibration of the model does not consider taxation at shareholder level, these results also apply to the case of new equity finance. The figures show that, deferred taxation is correctly incorporated into the model, the intertemporal evolution of the EMTR 
is much closer to that of the SCTR than predicted by the unconstrained model. Therefore, falling capital allowances had little impact on the evolution of the tax burden on income from capital and the EMTR has been declining over time in both countries. The two figures also show that enhanced capital allowances temporarily provided in the United States in the early 2000s and in the United Kingdom during the early 1990s had little impact on the EMTR. In turn, this also suggests that the effectiveness of higher capital allowances as a fiscal policy tool to provide an incentive for capital accumulation during an economic recession is probably largely overstated by the standard analysis. This is a very important implication for tax policy analysis, since both the United States and the United Kingdom have increased tax allowances on capital spending in an attempt to encourage private sector investment and promote faster economic growth after the 20072009 financial crisis and global economic downturn. ${ }^{16}$

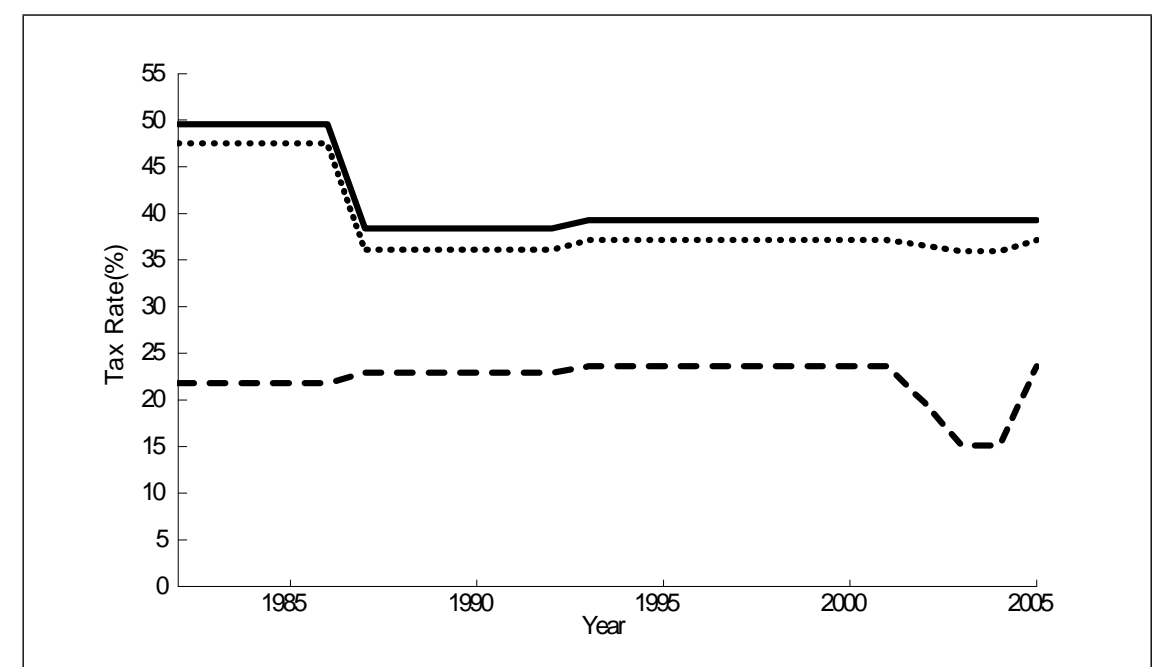

Figure 7: SCTR ( - ), $\operatorname{EMTR}_{U}(---)$ and $\operatorname{EMTR}_{C}(\cdots)$ on domestic investment in plant and machinery financed by retained earnings or new equity in the United States from 1982 to 2005. Taxation at shareholder level is not included.

\footnotetext{
${ }^{16}$ The 2009 American Recovery and Reinvestment Act (ARRA) has allowed additional firstyear depreciation of 50 per cent of purchase cost by extending for one year the depreciation bonus created by the 2008 Economic Stimulus Act. The HM Treasury Budget 2009 has also announced a one-year increase in capital allowances from 20 to 40 per cent.
} 


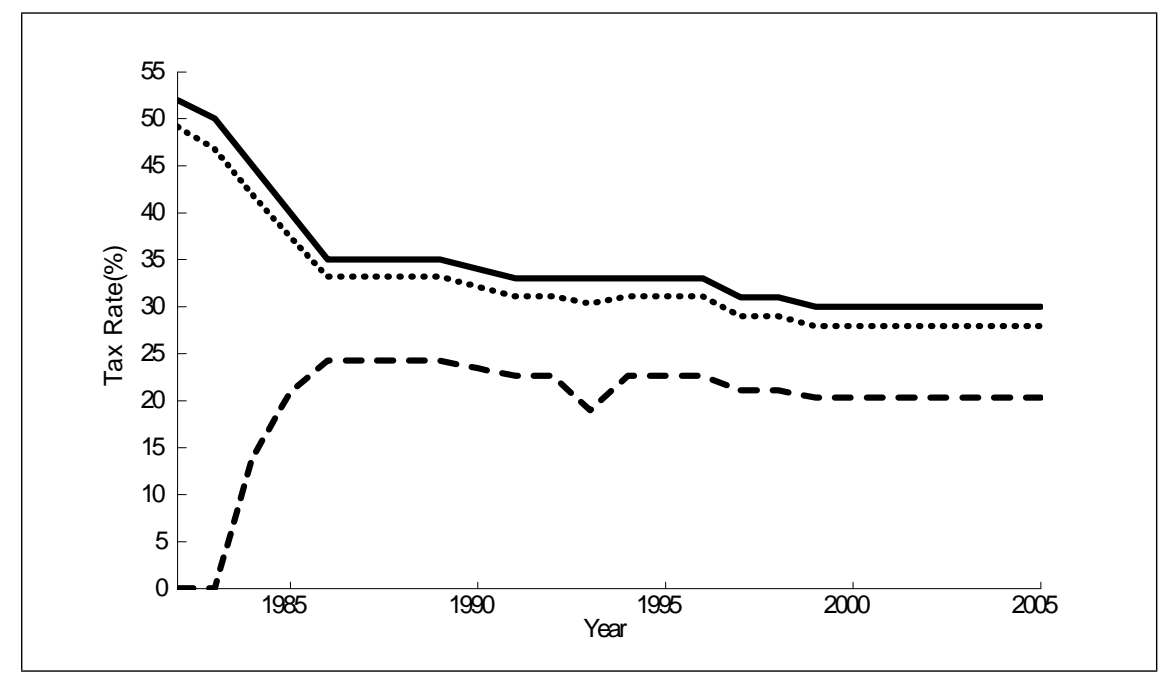

Figure 8: SCTR ( - ), EMTR $\operatorname{EM}_{U}(---)$ and $\operatorname{EMTR}_{C}(\cdots)$ on domestic investment in plant and machinery financed by either retained earnings or new equity in the United Kingdom from 1982 to 2005. Taxation at shareholder level is not included.

Figures 9 and 10 consider the evolution of the EMTR in the United States and the United Kingdom under debt-financed domestic investment. As mentioned in Section 2, the EMTR on income from capital is less than zero - meaning that the tax code is indeed granting an investment subsidy to firms when firms can deduct the cost of capital entirely as under debt finance the tax allowance for capital spending exceeds the economic depreciation. Therefore, the two figures show that the financial constraint on domestic investment financed by debt has the effect of almost entirely neutralising the impact of variations in capital allowances, in turn restoring tax neutrality under debt-financed investment. 


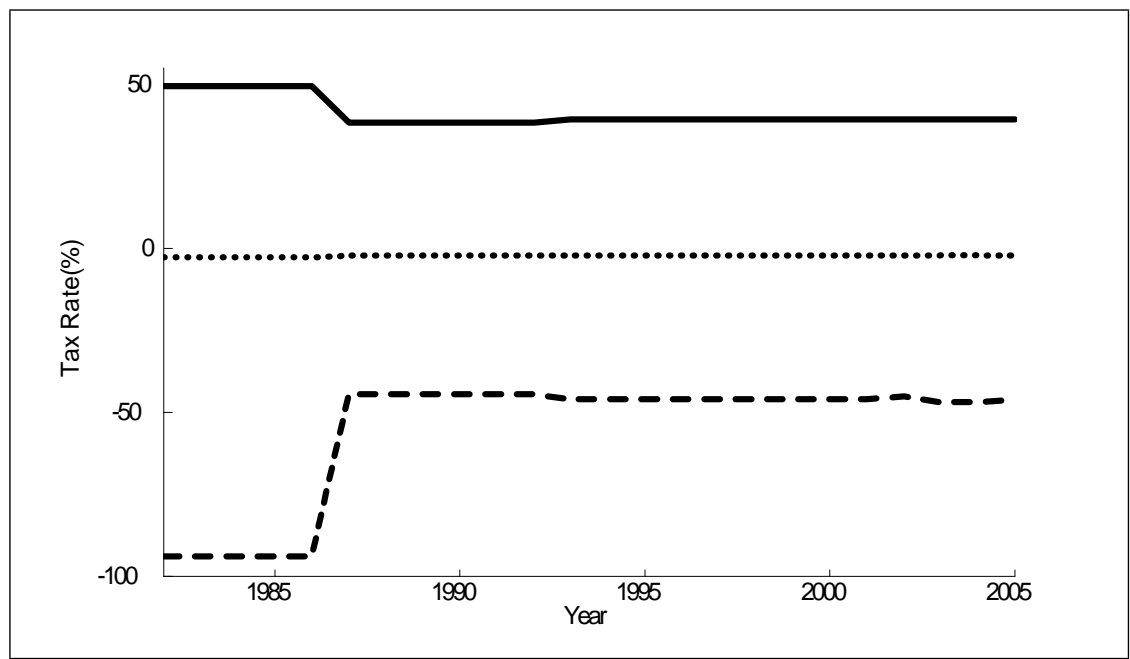

Figure 9: $\operatorname{SCTR}(-), \operatorname{EMTR}_{U}(---)$ and $\operatorname{EMTR}_{C}(\cdots)$ on domestic investment in plant and machinery financed by debt in the United States from 1982 to 2005 . Taxation at shareholder level is not included.

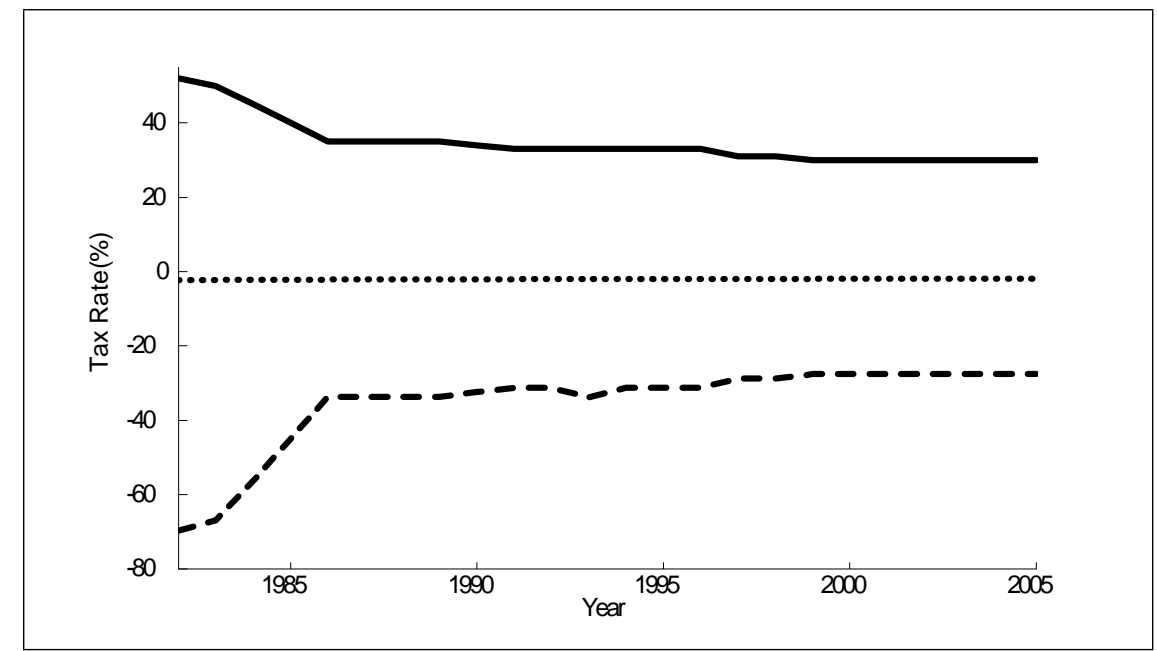

Figure 10: $\operatorname{SCTR}(-), \operatorname{EMTR}_{U}(---)$ and $\operatorname{EMTR}_{C}(\cdots)$ on domestic investment in plant and machinery financed by debt in the United Kingdom from 1982 to 2005. Taxation at shareholder level is not included.

Table 1 quantifies the patterns presented in Figures 7 to 10. The unconstrained model predicts that when investment is financed by either retained earnings or new equity the average EMTR is well below the average SCTR, while debt financing coupled with enhanced capital allowances has resulted in a negative EMTR, on average, over the period 1982-2005. In contrast, once financial constraints are correctly incorporated into the model, the EMTR on investment financed by retained earnings or new equity has been, 
on average, quite close to the average statutory tax rate, while being close to zero for debt-financed investment. ${ }^{17}$

\begin{tabular}{l|ccccc}
\hline \hline & SCTR & $\begin{array}{c}\mathrm{EMTR}_{U} \\
\text { Equity finance }\end{array}$ & $\begin{array}{c}\mathrm{EMTR}_{C} \\
\text { UMTR } \\
\text { Debt finance }\end{array}$ & $\mathrm{EMTR}_{C}$ \\
\hline & \multicolumn{5}{|c}{ United States } \\
\hline 1982 & 50 & 22 & 48 & -94 & -2.8 \\
2005 & 39 & 24 & 37 & -46 & -2.2 \\
Average & 41 & 22 & 39 & -56 & -2.3 \\
St. Dev. & 4.4 & 2.4 & 4.5 & 20.1 & 0.2 \\
\hline & \multicolumn{5}{c}{ United Kingdom } \\
\hline 1982 & 52 & 0 & 49 & -70 & -2.3 \\
2005 & 30 & 20 & 28 & -28 & -1.9 \\
Average & 35 & 20 & 33 & -35 & -2.0 \\
St. Dev. & 6.1 & 6.5 & 5.8 & 12.0 & 0.1 \\
\hline \hline
\end{tabular}

Table 1: Descriptive statistics: statutory corporate and effective marginal tax rates in the United States and in the United Kingdom, 1982-2005.

Finally, the robustness of these findings is explored along a number of different profiles. First, the computation of EMTR is extended to take into account taxation at personal level (hence $\gamma \neq 1$ ) in both countries under the three forms of finance. Figure 11 plots the evolution of the average EMTR resulting in each country after assuming that investment is financed 55 per cent by retained earnings, 10 per cent by new equity and 35 per cent by debt. ${ }^{18}$ Figure 12 presents average EMTRs time series for investment in industrial buildings, whereas figure 13 plots average EMTRs time series on an investment including both plant and machinery and industrial buildings. Finally, figures 14 and 15 examine the effect of accounting depreciation being higher or lower than economic depreciation. Visual inspection of these results corroborates the previous evidence on the intertemporal evolution of the effective tax burden on income from capital in the United States and the United Kingdom over the last 25 years: the EMTR has declined in both countries regardless of the form of investment finance and the type of investment asset. The declining pattern of the EMTR is also independent from the gap between economic and accounting depreciation: given economic and tax rates of depreciation, the higher is the rate of accounting depreciation, the lower is the EMTR relative to the SCTR, since this contributes to reduce the size of provisions for deferred taxes in turn limiting their impact on the EMTR.

\footnotetext{
${ }^{17}$ Similar empirical results to those described in this section are also obtained when considering domestic investment in industrial buildings. These results are not reported in the paper for reasons of space, but are available from the author upon request.

${ }^{18}$ These shares are taken from Chennells and Griffith (1997).
} 


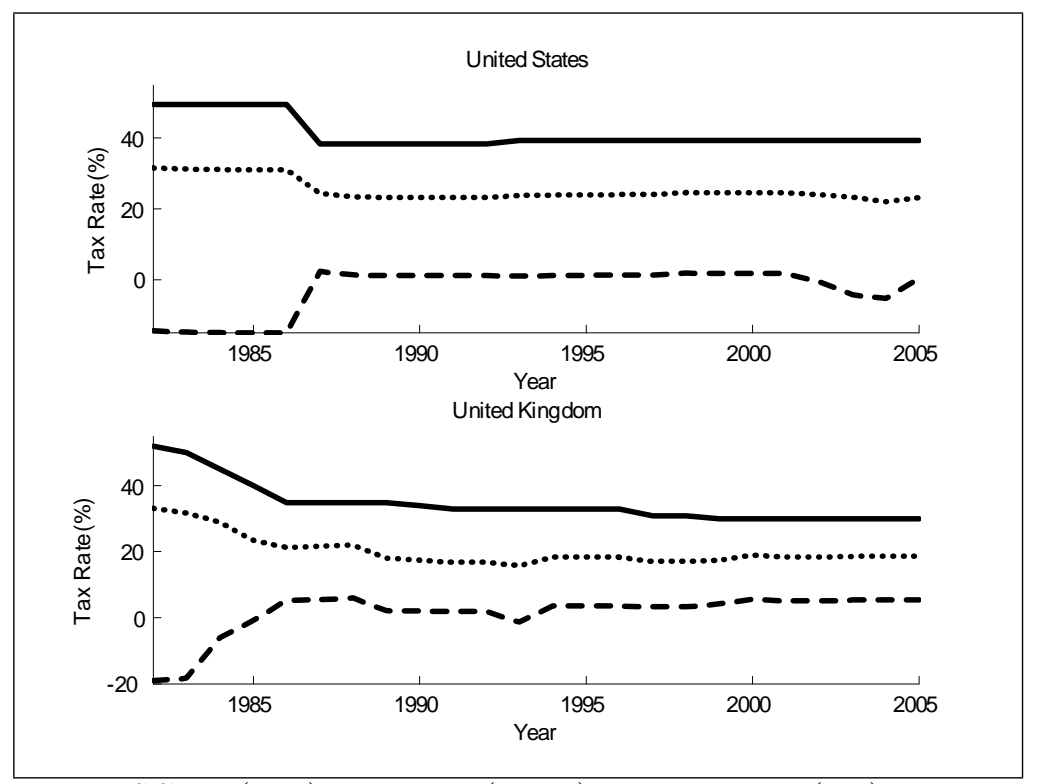

Figure 11: $\operatorname{SCTR}(-), \operatorname{EMTR}_{U}(---)$ and $\operatorname{EMTR}_{C}(\cdots)$ on domestic investment in plant and machinery financed by retained earnings $(55 \%)$, new equity (10\%) and debt (35\%). Taxation at shareholder level included.

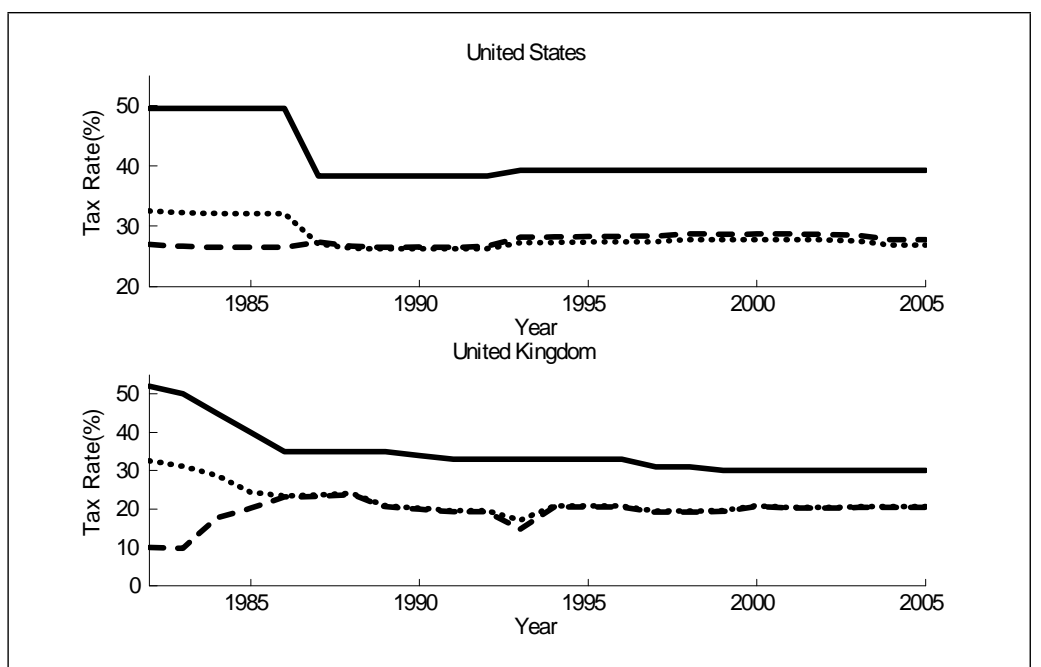

Figure 12: SCTR ( - ), $\operatorname{EMTR}_{U}(---)$ and $\operatorname{EMTR}_{C}(\cdots)$ on domestic investment in industrial buildings financed by retained earnings (55\%), new equity (10\%) and debt (35\%) from 1982 to 2005. Taxation at shareholder level included. 


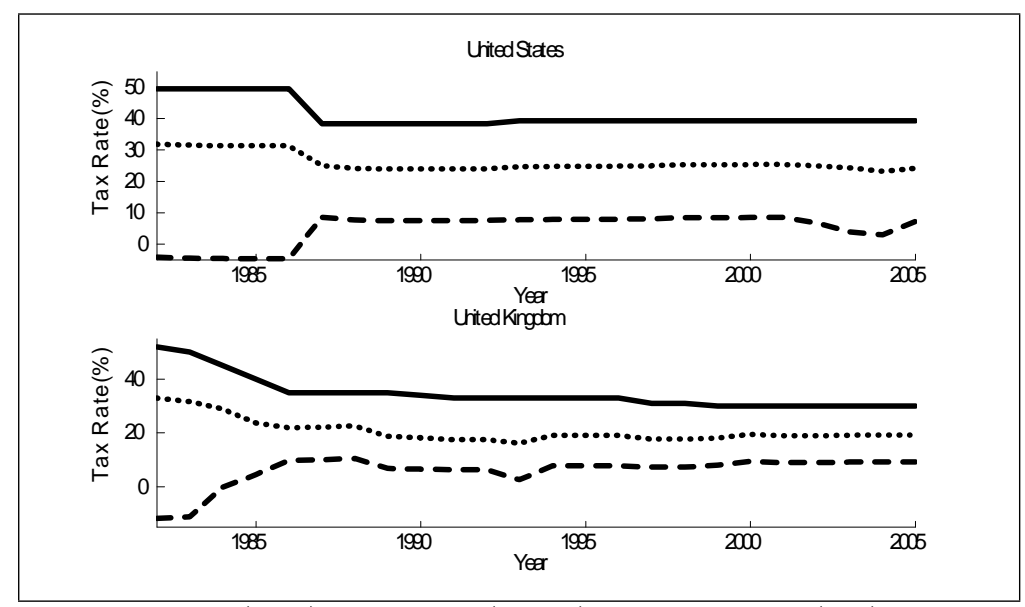

Figure 13: SCTR (- ), EMTR $\operatorname{EM}_{U}(---)$ and $\operatorname{EMTR}_{C}(\cdots)$ on domestic investment in plant and machinery (75\%) and industrial buildings $(25 \%)$ financed by retained earnings (55\%), new equity (10\%) and debt (35\%) from 1982 to 2005. Taxation at shareholder level included.

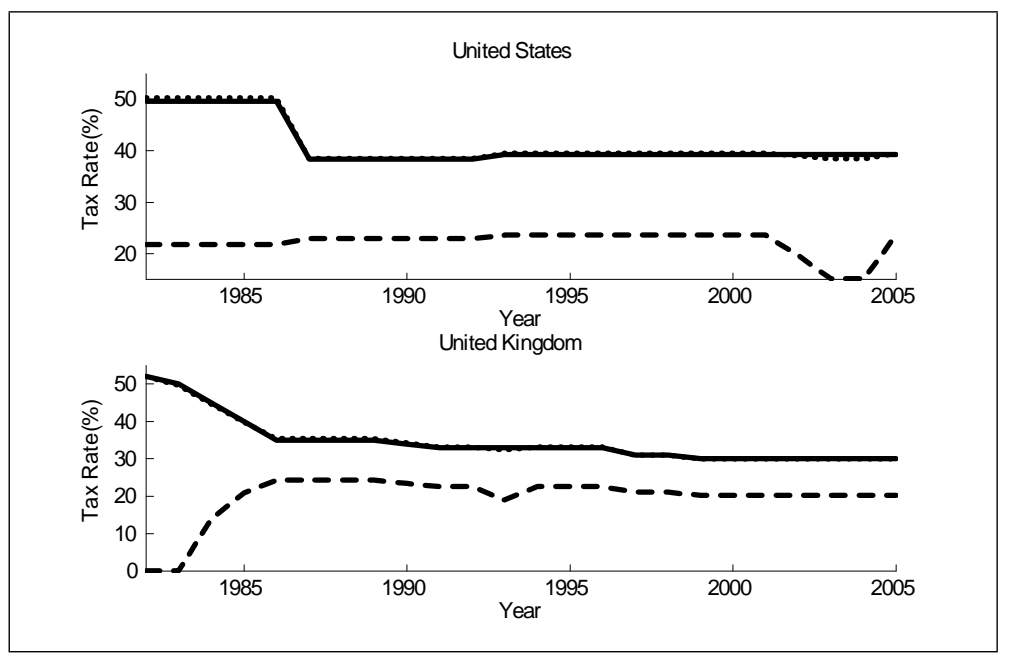

Figure 14: SCTR ( - ), EMTR $\operatorname{EM}_{U}(---)$ and $\operatorname{EMTR}_{C}(\cdots)$ on domestic investment in plant and machinery financed by retained earnings or new equity from 1982 to 2005. Taxation at shareholder level is not included. Accounting depreciation rate $10 \%$, economic depreciation rate $12.5 \%$. 


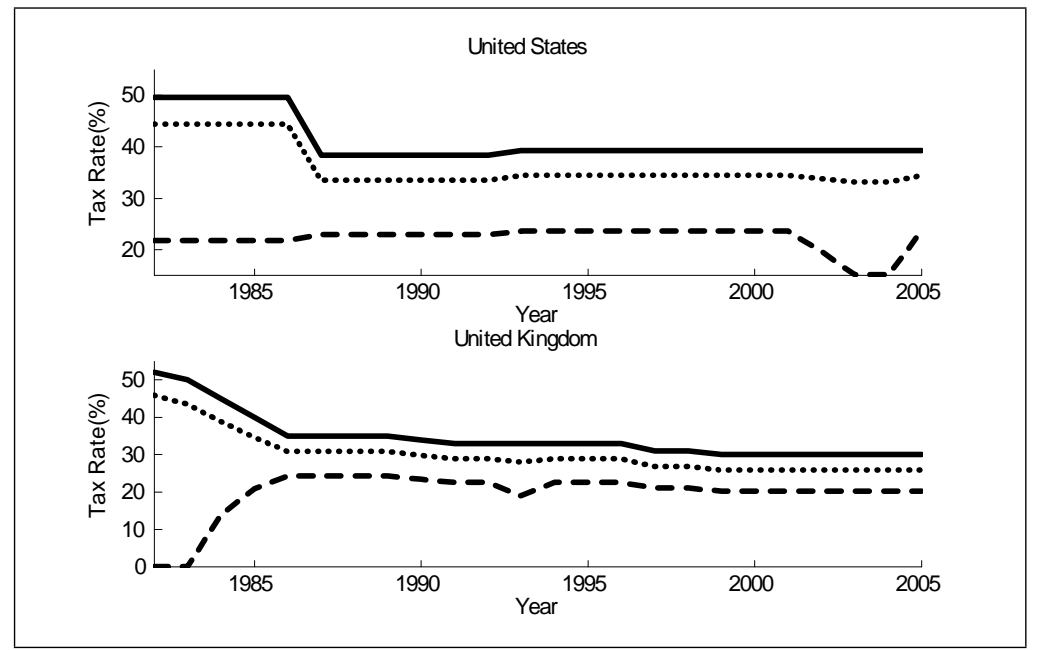

Figure 15: SCTR ( - ), EMTR $\operatorname{EM}_{U}(---)$ and $\operatorname{EMTR}_{C}(\cdots)$ on domestic investment in plant and machinery financed by retained earnings or new equity from 1982 to 2005. Taxation at shareholder level is not included. Accounting depreciation rate $15 \%$, economic depreciation rate $12.5 \%$.

\section{Conclusion}

The need to produce measures of the EMTR on income from capital is important not only as a scientific exercise, but also for tax policy analysis and planning tax reforms. Such an approach, which has roots in the early work by King and Fullerton in the 1980s and has been subsequently developed by Devereux and Griffith, yields time series of the EMTR which show that, regardless of the form of finance, the corporate tax burden has increased in both the United States and the United Kingdom over the last 25 years. This trend contradicts the traditional economic wisdom, which instead suggests that the EMTR should fall over time as a result of increasing capital mobility and tax competition. This paper shows that this contradiction between theory and evidence arises because the computation of the EMTR omits the effect of dividend policy constraints faced by firms in the United States and the United Kingdom. Company law in both countries encompasses the fundamental principle that the capital share must be maintained in the corporate sector, and thus imposes financial constraints on dividend policy which prevent firms from distributing to shareholders any tax saving arising from enhanced capital allowances. The paper extends previous research in this area by incorporating financial constraints into the framework for the computation of the EMTR prescribed by Devereux-Griffith (1998b, 2003) and re-computes time series of the EMTR under the new constrained model in both countries over the period 1982-2005. The new empirical results show - in sharp contrast with the existing evidence - that the EMTR on investment financed by either retained earnings or new equity has indeed declined over time, as predicted by the literature on corporate tax competition. On the other hand, 
time series of the EMTR on debt-financed investment have been relatively stable over time because financial constraints on dividend policy have the ultimate effect of neutralising the beneficial impact on the user cost of capital due to the excess of capital allowances over economic depreciation.

\section{References}

Alexander, D. and S. Archer (2009). 2009 International Accounting/Financial Reporting Standard Guide. CCH Incorporated.

Alworth, J. S. (1979). "Investment Incentives, Corporate Taxation and Efficiency in the Allocation of Capital - A Comment", Economic Journal, 89, 355, 663-665.

Atkinson, A. B. and J. E. Stiglitz (1980). Lectures on Public Economics. McGraw-Hill.

Backus, D., Henriksen, E. and K. Storesletten (2008). "Taxes and the global allocation of capital", Journal of Monetary Economics, 55, 48-61.

Boadway, R. W. and N. Bruce (1979). "Depreciation and Interest Deductions and the Effect of the Corporation Income Tax on Investment", Journal of Public Economics, 11, 1, 93-105.

Bordignon, M., S. Giannini and P. Panteghini (1999). "Corporate Taxation in Italy: An Analysis of the 1998 Reform", Finanzarchiv, 56, 335-362.

Burnham, P. and L. Ozanne (2006). "Distortions from Partial Tax Reform Revealed through Effective Tax Rates", National Tax Journal, 59, 3, 611-630.

Chennells, L. and R. Griffith (1997). Taxing Profits in a Changing World. Institute for Fiscal Studies: London.

Congressional Budget Office (2005). Taxing Capital Income: Effective Rates and Approaches to Reform. Congressional Budget Office, Washington.

Congressional Budget Office (2006). Computing Effective Tax Rates on Capital Income. Congressional Budget Office, Washington.

De Mooij, R., A. and S. Ederveen (2003). "Taxation and Foreign Direct Investment: A Synthesis of Empirical Research", International Tax and Public Finance, 10, 6, 673-693.

Devereux, M. P. and R. Griffith (1998a) "Taxes and the Location of Production: Evidence from a Panel of US Multinationals" Journal of Public Economics, 68, 3, 335-367. 
Devereux, M. P. and R. Griffith (1998b). The Taxation of Discrete Investment Choices. Institute for Fiscal Studies: London.

Devereux, M. P. and R. Griffith (2003). "Evaluating Tax Policy for Location Decisions", International Tax and Public Finance, 10, 2, 107-126.

Devereux, M. P., R. Griffith and A. Klemm (2002). "Corporate Income Tax Reforms and International Tax Competition", Economic Policy, 17, 35, 451-495.

Devereux, M. P., Lockwood, B. and M. Redoano (2008). "Do Countries Compete over Corporate Tax Rates?", Journal of Public Economics, 92, 12101235 .

Ernst \& Young (2003). Company Taxation in the New EU Member States. Ernst \& Young.

European Commission (1992). Ruding Report, Sec (92) 1118, Brussels: European Commission.

European Commission (2001). "Company Taxation in the Internal Market", Commission Staff Working Paper, COM (2001) 582 final, Brussels: European Commission.

Fuest, C., B. Huber and J. Mintz (2005). "Capital Mobility and Tax Competition", Foundations and Trends in Microeconomics, 1, 1-62.

Garretsen, H. and J. Peeters (2007). "Capital Mobility, Agglomeration and Corporate Tax Rates: Is the Race to the Bottom for Real?". CESifo Economic Studies, 53, 2, 263-293.

Institute for Fiscal Studies (2009). Mirrlees Review: Reforming the Tax System for the 21st Century. London: Institute for Fiscal Studies.

Jorgenson, D. W. (1963). "Capital Theory and Investment Behavior", American Economic Review, 53, 2, 247-259.

Jorgenson, D. W. and R. E. Hall (1967). "Tax Policy and Investment Behavior", American Economic Review, 57, 3, 391-414.

Kanniainen, V. and J. Södersten (1994). "Costs of Monitoring and Corporate Taxation", Journal of Public Economics, 55, 2, 307-321.

Kanniainen, V. and J. Södersten (1995). "The Importance of Reporting Conventions for the Theory of Corporate Taxation", Journal of Public Economics, 57, 3, 417-430. 
King, M. A. (1974). "Taxation and the Cost of Capital", Review of Economic Studies, 41, 1, 21-35.

King, M. A. and D. Fullerton (eds) (1984). The Taxation of Income from Capital: A Comparative Study of the United States, the United Kingdom, Sweden and West Germany. University of Chicago Press.

OECD (1991). Taxing Profits in a Global Economy: Domestic and International Issues. Paris: OECD.

OECD (2007). Fundamental Reform of Corporate Income Tax. OECD Tax Policy Studies, 16. Paris: OECD.

Polito, V. (2009). "Measuring the Effective Tax Burden in the Real World", Fiscal Studies, 30, 2, 247-278.

Sinn, H.-W. (1987). Capital Income Taxation and Resource Allocation. North-Holland, Amsterdam.

Slemrod, J. (1990). "Tax Effects on Foreign Direct Investment in the US: Evidence from a Cross-Country Comparison." In A. Razin and J. Slemrod (eds.), Taxation in the Global Economy. University of Chicago Press.

Sørensen, P. B. (1995). "Changing Views of the Corporate Income Tax", National Tax Journal, 48, 2, 279-294.

Wilson, J. D. (1999). "Theories of tax competition", National Tax Journal, $52,269-304$. 